\title{
Wave Refraction, River Damming, and Episodes of Severe Shoreline Erosion: The São Francisco River Mouth, Northeastern Brazil
}

\author{
Author(s) :Abílio Carlos Da Silva Pinto Bittencourt, José Maria Landim Dominguez, Luiz Carlos S.
} Fontes, Daiana Leite Sousa, Iracema Reimão Silva, and Franz Rangel Da Silva

Source: Journal of Coastal Research, Number 234:930-938. 2007.

Published By: Coastal Education and Research Foundation

DOI:

URL: http://www.bioone.org/doi/full/10.2112/05-0600.1

BioOne (www.bioone.org) is a a nonprofit, online aggregation of core research in the biological, ecological, and environmental sciences. BioOne provides a sustainable online platform for over 170 journals and books published by nonprofit societies, associations, museums, institutions, and presses.

Your use of this PDF, the BioOne Web site, and all posted and associated content indicates your acceptance of BioOne's Terms of Use, available at www.bioone.org/page/terms_of_use.

Usage of BioOne content is strictly limited to personal, educational, and non-commercial use. Commercial inquiries or rights and permissions requests should be directed to the individual publisher as copyright holder. 


\title{
Wave Refraction, River Damming, and Episodes of Severe Shoreline Erosion: The São Francisco River Mouth, Northeastern Brazil
}

\author{
Abílio Carlos Da Silva Pinto Bittencourt ${ }^{\dagger}$, José Maria Landim Dominguez ${ }^{\ddagger}$, Luiz Carlos S. Fontes ${ }^{\S}$, \\ Daiana Leite Sousa ${ }^{\dagger \dagger}$, Iracema Reimão Silva ${ }^{\dagger}$, Franz Rangel Da Silva ${ }^{\S \S}$ \\ Laboratório de Estudos Costeiros \\ Centro do Pesquisa en Geofisica e \\ Geologia \\ Instituto de Geociências-UFBA \\ Campus Universitário da Federação \\ 40170-290 Salvador-Bahia, Brazil \\ abílio@cpgg.ufba.br. \\ Curso de Graduação em Geologia- \\ UFBA \\ Campus Universitário da Federação \\ 40170-290 Salvador-Bahia, Brazil \\ *Laboratório de Estudos Costeiros \\ (CPGG) \\ Instituto de Geociências-UFBA \\ Campus Universitário da Federação \\ 40170-290 Salvador-Bahia, Brazil \\ §Curso de Pós-Graduação em Geologia- \\ Universidade Federal do Bahia \\ Campus Universitário da Federação \\ 40170-290 Salvador-Bahia, Brazil \\ *Mestrado em Planejamento Territorial \\ e Desenvolvimento Social \\ Universidade Católica do Salvador \\ Av. Anita Garibaldi no 2981 \\ 41940-450 Salvador-Bahia, Brazil \\ $\$$ Geohidro Consultoria, Avenida ACM, \\ 3840 \\ Ed. Capemi, $1^{\circ}$ andar, Pituba \\ 41821-900 Salvador-Bahia, Brazil
}

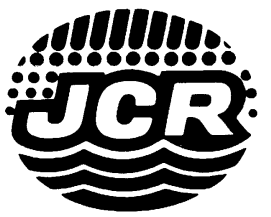

\begin{abstract}
BITTENCOURT, A.C.S.P.; DOMINGUEZ, J.M.L.; FONTES, L.C.S.; SOUSA, D.L.; SILVA, I.R., and DA SILVA, F.R., 2007. Wave refraction, river damming, and episodes of severe shoreline erosion: The São Francisco River mouth, northeastern Brazil. Journal of Coastal Research, 23(4), 930-938. West Palm Beach (Florida), ISSN 0749-0208.

The São Francisco River mouth is undergoing a severe erosional process that has caused the destruction of a village and the partial immersion of a lighthouse constructed in 1856. The present work comprises an historic time evaluation of this phenomenon based on the analysis of the sediment dispersion patterns caused by waves along three distinct shoreline traces. For this, we define a wave climate model based on the construction of refraction diagrams, which are assumed to be valid for the three shorelines. The resulting sediment transport patterns obtained by numerical modeling from the refraction diagrams - taking into account the angle of approach and the wave height along the coast-allow us to establish a first-order correlation between coastal dynamics and erosion phenomenon. The results also suggest that a permanent reduction in the solid river discharge, in response to the construction of large dams, probably will have two direct consequences in the river mouth region: (i) a chronic shoreline erosion downdrift of the mouth and (ii) a progressive deflection of the mouth in the downdrift direction.
\end{abstract}

ADDITIONAL INDEX WORDS: Longshore drift, numerical modeling, coastal evolution, river mouth bar, wave-dominated delta, human impacts.

\section{INTRODUCTION}

The São Francisco River mouth (Figure 1) is currently experiencing a severe erosive process that has already destroyed the village of Cabeço, located on its right bank, as well as caused the partial immersion of a lighthouse built in 1856 (Figure 2). At the time of its construction, the lighthouse was located approximately $280 \mathrm{~m}$ inland from the shoreline (FONTES, 2001), and in 2005 was partially below sea level, at a distance of approximately $200 \mathrm{~m}$ from the shoreline (Figure $3)$. On the left of the river bank, the erosive phenomenon is much less accentuated. Among the authors that have analyzed this subject, there is a consensus in attributing the magnitude of this erosive process to a significant reduction in the discharge of solids in the lower river course, which is

DOI:10.2112/05-0600.1 received 07 October 2005; accepted in revision 14 February 2006. the result of the construction of a series of dams along its course (Dominguez et al., 2003; Fontes, 2001; Oliveira et al., 2003; Silva et al., 2001; Vital et al., 2001). Based on qualitative analysis of wave refraction diagrams, DominGUEZ (1999) proposed that this erosive process is probably the result of modifications in the wave refraction patterns caused by geometric changes around the mouth bar. Later on, OLIVEIRA (2003) evaluated the erosional problem along the coast of the State of Sergipe (Figure 1), including the coastal section of the São Francisco River mouth. Based on a quantitative analysis of wave refraction diagrams, constructed on the scale of 1:300,000, OLIVEIRA (2003) concluded that the right bank erosion in the São Francisco River mouth may be due to a divergence in the direction of net longshore drift of sediments, which generates a local deficit of sediments that is not compensated by river deposition.

The aim of the present paper is to evaluate and clarify this severe coastal erosion phenomena associated with the São 


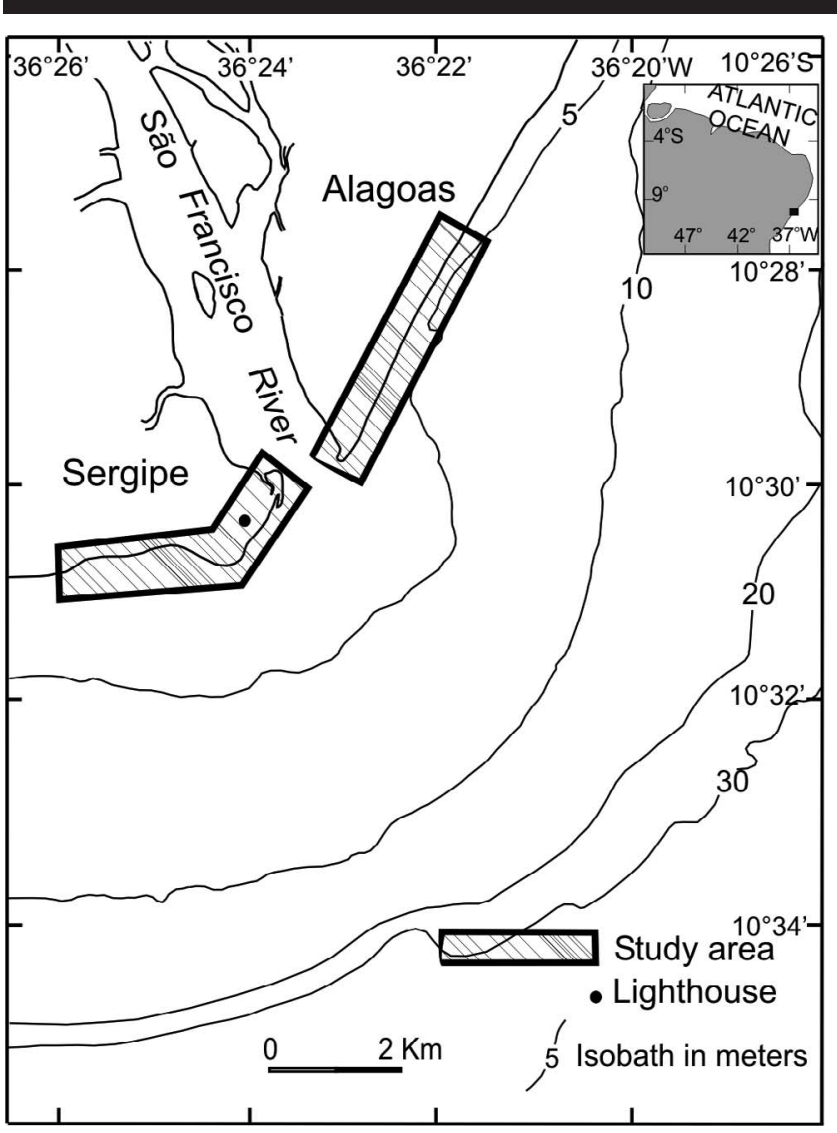

Figure 1. Physiographic characteristics of the mouth of the São Francisco River and the internal continental shelf for the year 1981 (according to DHN, 1983).

Francisco River mouth, based on the analysis of sediment dispersion patterns driven by sea wave motions.

\section{GEOLOGICAL-PHYSIOGRAPHIC SETTING}

Historically, the coastal plain of the São Francisco River mouth has been considered as a classic example of a "wavedominated delta." Its evolution has been fundamentally conditioned by the struggle between the river and the waves (Baccocoli, 1971; Galloway, 1975; Wright and ColeMAN, 1973). BitTencourt et al. (1982), Dominguez et al. (1987), and Dominguez (1996) all have highlight the roles played by longshore drift of sediments and the relative sealevel variations in the area. BHATTACHARYA and GIOSAN (2003) proposed denominating this coastal system as an "asymmetric wave-influenced delta."

The coastal plain associated with the São Francisco River mouth extends over a shoreline of approximately $75 \mathrm{~km}$, with a maximum width of $25 \mathrm{~km}$. This plain is composed of Quaternary deposits, including regressive coastal sand deposits, alluvial fans, mangroves, fluvial terraces and dunes (BARBOsA and Dominguez, 2003; Bittencourt et al., 1982; Dominguez, 1996).

The longshore sediment drift in the study region is oriented from NE to SW (BitTencourt et al., 1982; Coleman and Wright, 1972; Dominguez, 1996; Dominguez et al., 1983). Therefore, updrift from the mouth, the coastal plain is basically fed by longshore drift of sediments ("groin effect"), while downdrift of the river, river sediments predominate (BHATTACHARYA and GiosAN, 2003; DomingueZ, 1996).

The continental shelf in front of the São Francisco River coastal plain has widths between 20 and $25 \mathrm{~km}$, with topographic gradients varying between 1:300 and 1:500, and a shelf break located at approximately $50 \mathrm{~m}$ depth (FRANÇA, 1979).

The region neighboring the São Francisco River mouth can be classified as having micro- and mesotides, with an equinoctial tide amplitude of $2.6 \mathrm{~m}$ and semidiurnal character.

The climate in the region of the São Francisco River mouth has a semihumid character, with four consecutive dry months per year. According to some authors, this dry season favors the development of a coastal field of dunes (BARBOSA and DominguEZ, 2003). The annual rainfall in the São Francisco River basin varies from $1250 \mathrm{~mm} / \mathrm{y}$ in its headwaters and in the coastal zone, to $500 \mathrm{~mm} / \mathrm{y}$ in its central portion (NIMER, 1989).

An outstanding hydrographic characteristic of the São Francisco River basin is the presence of nine dams along its course, constructed to regulate urban water supplies and flood controls and to attain giant irrigation projects and production of electric energy. These dams have caused drastic modifications in the river hydro-sedimentological characteristics, as can be seen in Figure 4, which shows the large variations in the average water flows in the lower São Francisco River (Fontes and HolandA, 2002). From this figure, it can be observed that: (i) from 1956 to 1978, there is a strong reduction in average water flows, (ii) from 1978 to 1985, significantly higher flows were reached, above those for 1978, and (iii) beginning in 1986, the flows dropped considerably, reaching the lowest average levels in this historical series. According to OlIVEIRA et al. (2003), between 1996 and 2002, the average observed flow was of $2000 \mathrm{~m}^{3} / \mathrm{s}$, well below the historical average of $2850 \mathrm{~m}^{3} / \mathrm{s}$. FONTES and HoLANDA (2002) attributed this drop to the flow regularization, controlled by dams, which became more effective in 1994, after the construction of the last dam on the lower course of the São Francisco River. This dam, located $190 \mathrm{~km}$ from the mouth, the last link in the sediment retention chain, reduced the total load of transported solids to $0.466 \times 10^{6} \mathrm{t} / \mathrm{y}$, representing only $3.8 \%$ of the sediment load carried to the São Francisco River mouth in the period prior to the dams' construction (OliveIRA et al., 2002). This figure is very close, for instance, to that reported by STANLEY and WARNER (1998) regarding the Nile River.

\section{VARIATIONS IN THE SHORELINE POSITION}

On the most external part of the coastal plain, on the right bank of the São Francisco River mouth, there are several sets of coastal Holocene beach-ridges presenting truncated patterns (Figure 5). These patterns are evidence that the line of the coastal mouth has not advanced to the ocean in a continuous manner; it has been interrupted by episodes of erosion 


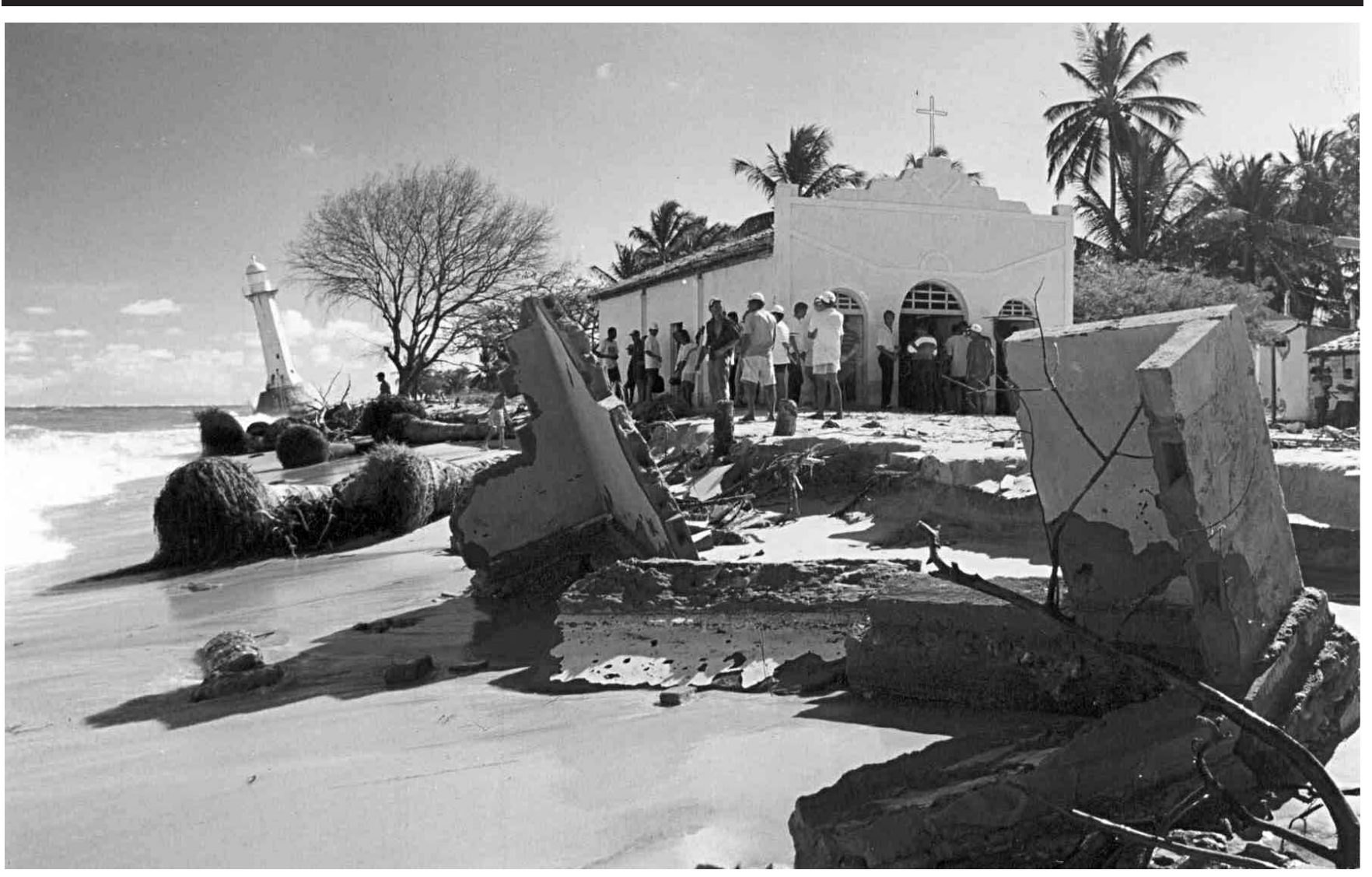

Figure 2. Village of Cabeço, partially destroyed (1998). In the background, the lighthouse can already be seen in the water (see text).

(Dominguez, 1999). In this same place, Dominguez (1999) has shown, based on comparative analysis of aerial photograph, satellite images, and nautical charts (Figure 6), that the shoreline has remained more or less stable between 1960 and 1981, prograding to a maximum distance of $1080 \mathrm{~m}$ in 1986. After this, a retreat culminated with the destruction of the village of Cabeço in 1998, which continues to this day. The rate of shoreline retreat between 1986 and 2001, of approximately $98.6 \mathrm{~m} / \mathrm{y}$, is comparable, for example, to that observed in some sections of the Nile delta (KomaR, 2000; White and El Asmar, 1999). Regarding the left bank of the estuary, Dominguez (1999) observed that, between 1960 and 1971 , the shoreline remained more or less stable, then retreated until 1981, approximately $240 \mathrm{~m}$, at the same time that it advanced to the south approximately $480 \mathrm{~m}$ (Figure 6). Later, between 1981 and 1986, this shoreline advanced to the east approximately $680 \mathrm{~m}$, followed by a retreat until 2001 of approximately 880 m (DoMINGUEZ, 1999; OLIVEIRA, 2003).

Dominguez et al. (2003) suggested that these modifications in the shoreline were related to natural variations in the discharge of solids and liquids of the São Francisco River. Superimposed on these natural variations is the last episode of severe shoreline erosion caused by sediment retention in large dams.

\section{WAVE CLIMATE MODEL}

Significant direct measurements of the wave regime for the area under study are not available. However, in the northeastern Brazilian region where this area is, sea-type waves predominate (DAVIES, 1972), that is, waves that are generated by local winds, a fact that is confirmed by wave statistics available in HoGBEN and LUMB (1967). According to data of the Brazilian Air Force meteorological station (BARBOSA, 1997), for the period from 1979 to 1988 in the coastal city of Aracaju, at an approximated distance of $100 \mathrm{~km}$ south of the São Francisco River mouth, the following wind directions and frequencies predominate: $\mathrm{NE}\left(\mathrm{N} 45^{\circ}\right) 19 \%$; $\mathrm{E}\left(\mathrm{N} 90^{\circ}\right) 49 \%$; and $\mathrm{SE}\left(\mathrm{N} 135^{\circ}\right) 32 \%$. The wave conditions used in this study were extracted from HoGBEN and LUMB (1967) (area 37) from data obtained in open the sea by visual observations made from ships. The wave data in HogBen and LumB (1967) are organized into angular sectors, which were grouped, for purposes of the present study, into three sets, as shown in Figure 7. To these sets wind frequencies of the same direction measured in the city of Aracaju were attributed.

It should be pointed out that the wave data used in this work have, naturally, uncertainties due to inaccuracies inherent in the manner in which they were obtained. The observer is determining some average height for the chaotic 


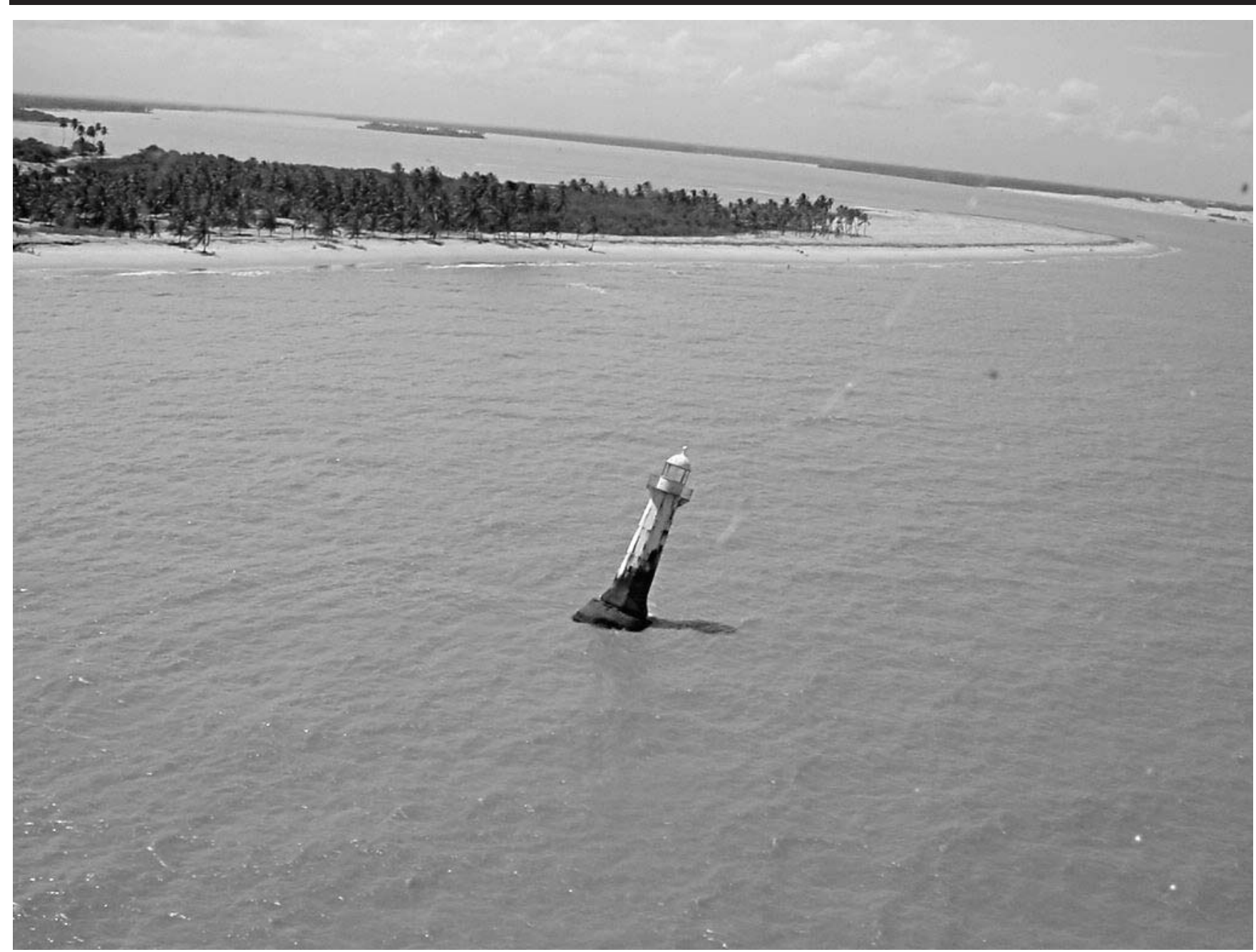

Figure 3. Right bank of the São Francisco River mouth, now without the village of Cabeço. The lighthouse can be seen already approximately $200 \mathrm{~m}$ from the shoreline (2002).

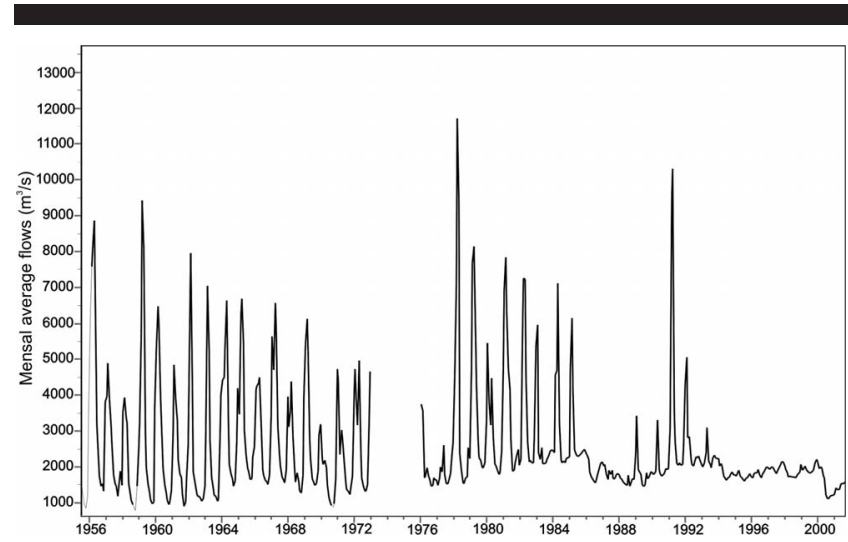

Figure 4. Average flows in the lower São Francisco River between 1956 and 2002, measured at the fluviometric station of Traipú, downstream from the system of dams and approximately $150 \mathrm{~km}$ from the mouth (according to Fontes and Holanda, 2002). wave surface (Young and Holland, 1996). Furthermore, the poor coverage given by ships should be considered, since they tend to follow standard routes.

Based on these data, refraction diagrams were constructed manually, in accordance with procedures described in CERC (1984), resulting in a generic wave climate model for the studied area. The bathymetric data used in the construction of these diagrams were extracted from the 1981 Nautical Chart of the Brazilian Navy (DHN, 1983), on the scale of 1:20,000 (Figure 1). Refraction diagrams were constructed for three distinct scenarios of the shoreline position: two with erosive characteristics, represented by the shorelines of 1981 and 2001, and a third with constructive characteristics corresponding to the shoreline of 1986 (Figures 6 and 8-10). For this, it was assumed that the bathymetry for 1981, for depths greater than $5 \mathrm{~m}$, remained unaltered during the 1981 to 2001 period. In this way, the refraction diagrams, constructed with the 1981 bathymetry, had the wave-rays refracted only to the isobath of $5 \mathrm{~m}$ and, from this point, maintained the 


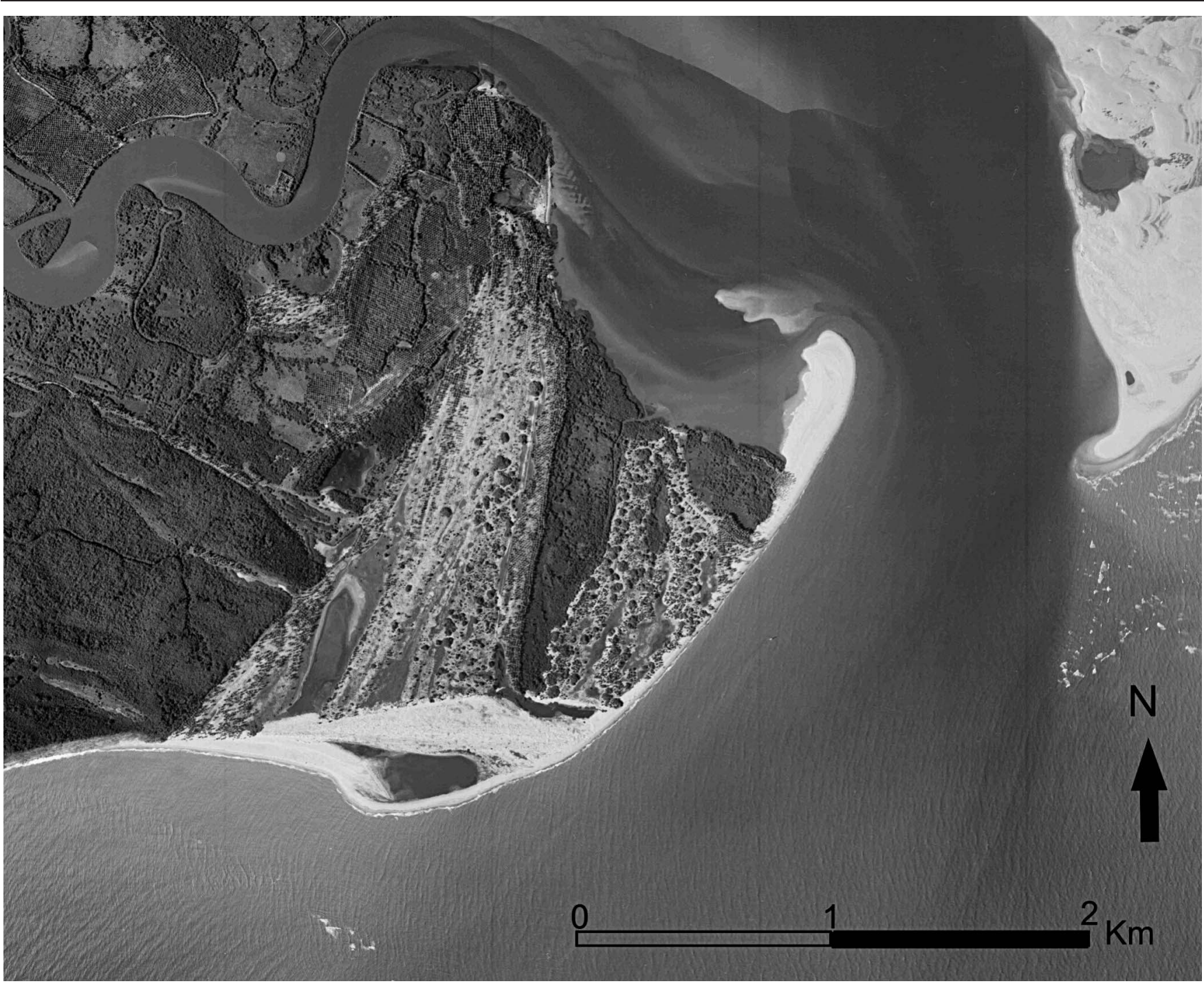

Figure 5. São Francisco River mouth in 2003 showing old truncated beach ridges.

last direction of propagation, extending to the shoreline of 1981, 1986, and 2001.

By examining Figures 8-10, it can be seen that the waves from NE are the ones that present more refraction. The waves from SE are the ones that present complex intercrossings of wave-rays and focuses of ray convergence along the shoreline.

\section{SEDIMENT DISPERSION PATTERNS}

Several formulas have been proposed to model the transport of sediments along the coast (CERC, 1984; KAMPHIUs, 1991, among others) that use different parameters including: direction and height of the wave, granulometry, sand porosity and density, water density, and environmental coefficients, among others. Considering the limitations imposed by the data quality, it was opted to adopt a simple approach, described in BitTEnCOURT et al. (2000, 2002, 2005), for the de- termination of the potential intensity of longshore drift of sediments. This approach considers that: (i) wave energy outside the break zone is directly proportional to the square of its height (DAviEs, 1972; MUNK and TRAYLOR, 1947); and (ii) the intensity of the longshore drift is proportional to the angle with which the wave-front strikes the coastline (Kокот, 1997; KomAR, 1976; ZenKOVITCH, 1967), in accordance with the function (KOMAR, 1976):

$$
y=\sin \alpha \times \cos \alpha,
$$

where $y$ is an intensity factor for the potential longshore drift, and $\alpha$ is the angle of incidence of the wave orthogonal to the shoreline. In this manner, potential longshore drift intensity can be expressed by a nondimensional number, according to the function:

$$
x=y H^{2},
$$




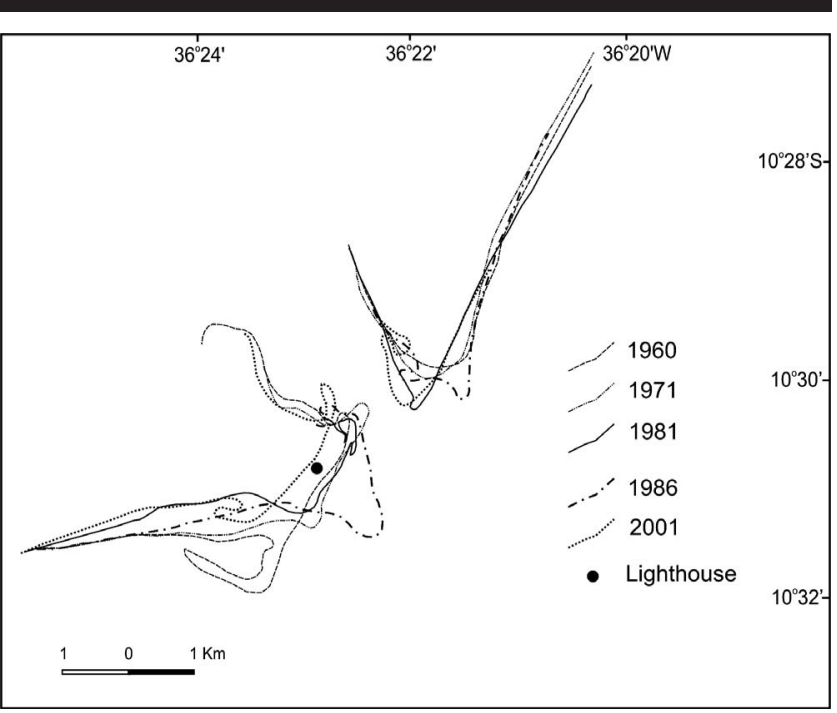

Figure 6. Coastlines in the São Francisco River mouth between the years 1960 and 2001 .

where $x$ is the intensity of the longshore drift and $H$ is the normalized wave height (i.e., the results were divided by a constant $1 \mathrm{~m}$ value). Wave height along the coastline was estimated in accordance with the equation (BASCOM, 1954):

$$
H=H_{0}\left(b_{0} / b\right)^{1 / 2},
$$

where the subscript zero designates deep water conditions and $b$ is the distance between sets of adjacent wave orthogonals. For the determination of the angle of wave incidence, the coastline was divided into rectilinear segments (Figures 8 to 10). Eventually, the same rectilinear segment was divided into two or more segments due to the fact that they present distinct patterns of separation between wave-rays, such as the case of segments IX and $\mathrm{X}$ in Figure 8IIIB. The distances $b$ and $b_{0}$ (Figures 8 to 10) were measured between the orthogonal limits of the set of orthogonals incident in each segment, or rarely, when this was not possible, by merging adjoining segments, such as segments VIII and IX in Figure 8ID. In this manner, an average wave height was obtained along the shoreline for the segment being considered. Angle $\alpha$ between each segment and a certain wave-front was the predominant one between the wave-rays incident in the segment, measured directly on the refraction diagram (Figures 8 to 10). Next, the value obtained for the drift intensity was multiplied by the percentage of annual wind direction frequency to which the considered wave front was associated. In the coastal sections presenting opposite wave drift direction during the year, the direction of net drift was defined considering the predominant direction given by the difference of intensity between opposing drifts.

From Figure 11 it can be seen that the general pattern of net longshore drift directions in the São Francisco River mouth is the same for the three modeled scenarios (shorelines of 1981, 1986, and 2001). In a general way, the direction for the net longshore drift is from NE to SW, confirming the eval-

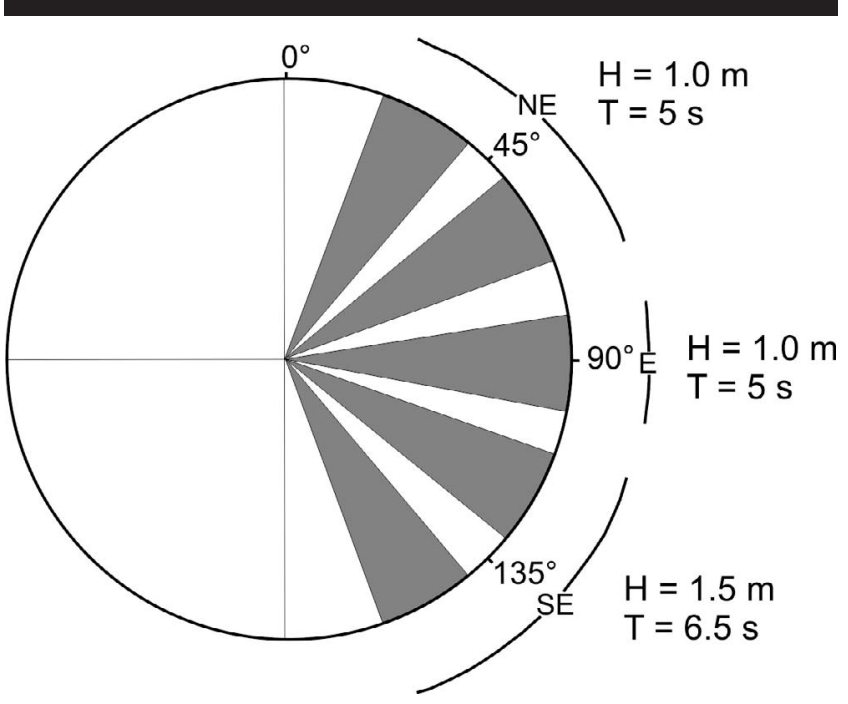

Figure 7. Representative scheme of the manner in which wave data are discriminated (bold areas) in Hogben and Lumb (1967) in the directions considered in the present paper; the average azimuths and predominant periods and corresponding heights are identified.

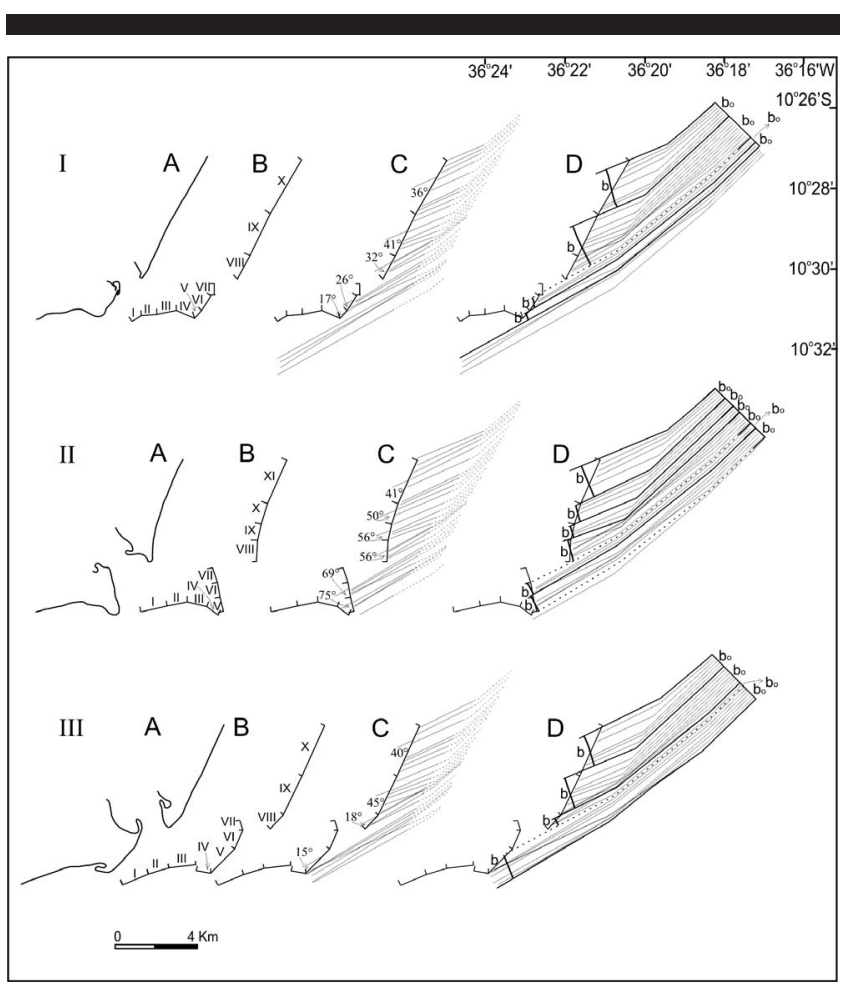

Figure 8. (IA, IIA, and IIIA) Coastlines in the São Francisco River mouth in 1981, 1986, and 2001, respectively. (B) Different segments into which the shoreline has been rectilinearized. (C) Incidence angles formed by the wave-rays in relation to the coastal segments. (D) Refraction diagrams for waves with a $5 \mathrm{~s}$ period, coming from $\mathrm{N} 45^{\circ}$. Measurements of $b$ and $b_{0}$ (see text), used to estimate wave height along the shore segments, are also shown. 


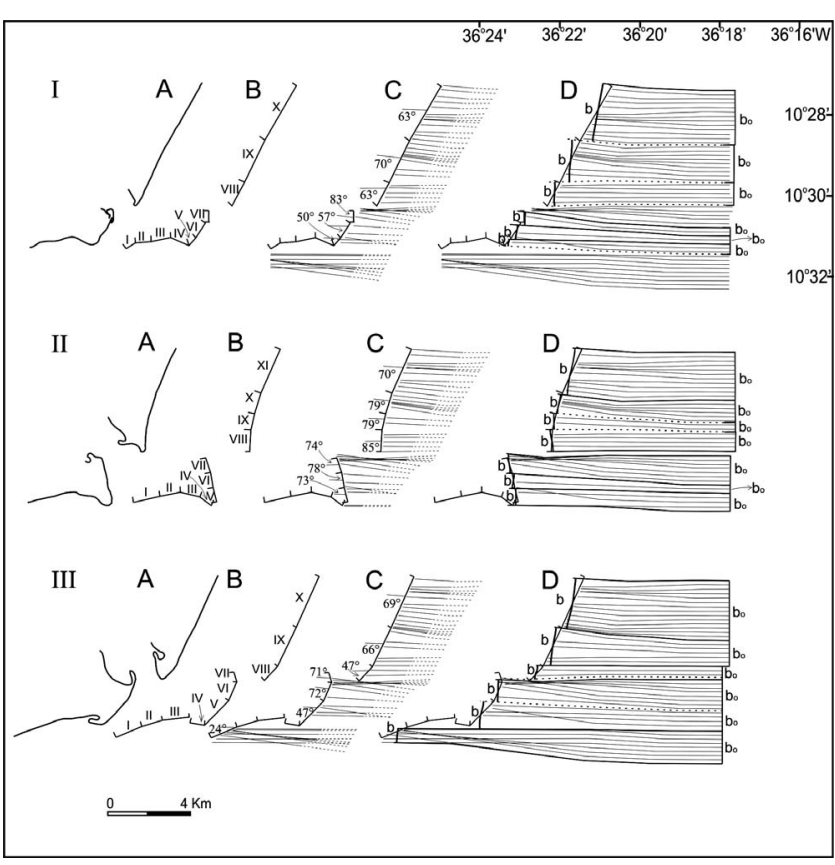

Figure 9. (IA, IIA, and IIIA) Coastlines in the São Francisco River mouth in 1981, 1986, and 2001, respectively. (B) Different segments into which the shoreline has been rectilinearized. (C) Incidence angles formed by the wave-rays in relation to the coastal segments. (D) Refraction diagrams for waves with a $5 \mathrm{~s}$ period, coming from $\mathrm{N} 90^{\circ}$. Measurements of $b$ and $b_{0}$ (see text), used to estimate wave height along the shore segments, are also shown.

uations of different authors previously mentioned. An exception is observed on the right bank, where there is a divergence in the drift direction, with the nodal points varying slightly in position between the three outlines of the shoreline. This divergence in drift direction regarding the 1981 shoreline has already been pointed out by OLIVEIRA (2003).

\section{DISCUSSION}

The shorelines updrift and downdrift of the São Francisco River mouth present differences in the dispersal patterns and in the supply of sediments (DOMINGUEZ, 1996; BHATTACHARYA and Giosan, 2003). Regarding the sediments supply, the updrift shoreline is fed by net longshore drift from NE to SW (Figure 11), which is retained in the mouth of the river by the "groin effect," while on the downdrift shoreline, sediment is basically supplied by the river. Regarding the sediment dispersal patterns, the shoreline on the downdrift side presents a divergence in the direction of net longshore drift of sediments that is not observed on the updrift shoreline, which has a single direction for net drift. This divergence is maintained during the three scenarios drawn for the modeled shoreline (Figure 11). Such conditions establish a deficit of sediments in the downdrift shoreline and, therefore, vulnerability to erosion, which needs an adequate supply of river sediment to be compensated.

The phases of progradation and retreat of the shoreline represented in Figure 6, observed by Dominguez et al.

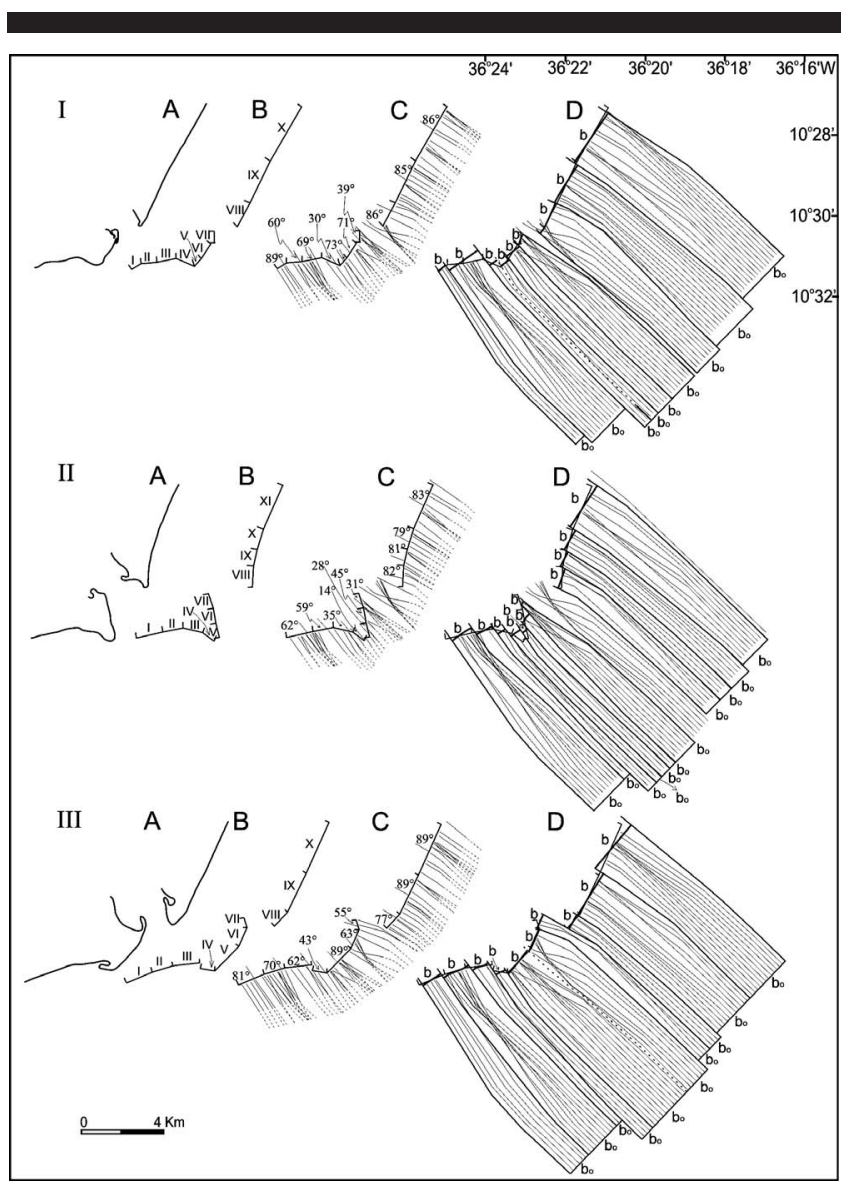

Figure 10. (IA, IIA, and IIIA) Coastlines in the São Francisco River mouth in 1981, 1986, and 2001, respectively. (B) Different segments into which the shoreline has been rectilinearized. (C) Incidence angles formed by the wave-rays in relation to the coastal segments. (D) Refraction diagrams for waves with a $6.5 \mathrm{~s}$ period, coming from $\mathrm{N} 135^{\circ}$. Measurements of $b$ and $b_{0}$ (see text), used to estimate wave height along the shore segments, are also shown.

(2003), can be better understood with the help of the sediment dispersal model proposed herein. Between 1960 and 1981, a retreat was observed in the updrift shoreline and its concomitant extension to the south. In the same period, in the section immediate downdrift, the shoreline remained practically unaltered, while a little further to the southwest, this same shoreline experienced erosion. These modifications seem to be related to decrease in average flows of the São Francisco River in the period between 1956 and 1978 (Figure 4). This decrease would cause a decrease in the "groin effect," producing a southward migration of the updrift bank, according to the mechanism described by Dominguez (1996). On the downdrift shoreline, the reduction in the solid discharge (here considered as directly proportional to the liquid discharge) would be responsible for the observed erosion effects.

The shoreline progradation phase observed on both banks of the São Francisco River between 1981 and 1986 can be also related to the large average river flows measured between 1978 and 1985 (Figure 4). On the updrift shoreline, an increase of the groin effect, resulting from these flows, would 


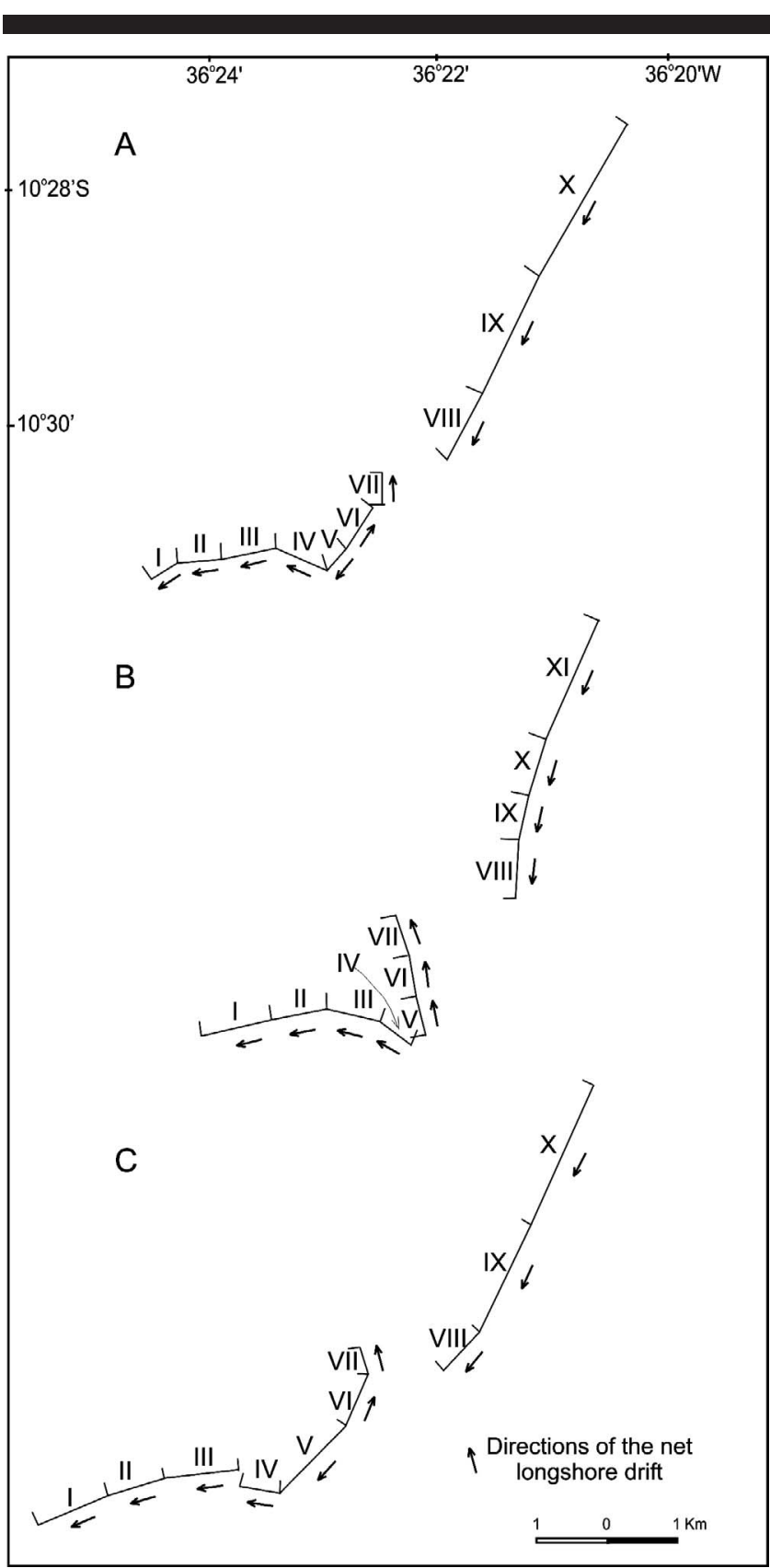

Figure 11. Directions of net longshore drift of sediments, computed in the present paper for each rectilinearized segment, corresponding to the coastlines in 1981 (A), 1986 (B), and 2001 (C).

have caused the progradation of the shoreline through the interruption of coastal transportation from NE to SW. On the downdrift shoreline, the increase in the discharge of solids also produced progradation of the shoreline in spite of the presence, in this section, of the divergence zone previously pointed out.

These tendencies were reversed in the 1986 to 2001 period, when the average flows underwent considerable reduction, mainly starting in 1994 (Figure 4), as a function of sediment retention by dams. During this river discharge reduction period, the groin effect became less effective, and the updrift shoreline from the mouth of the river started to experience erosion of the material deposited in the previous phase, according to the mechanism described in Dominguez (1996). On the downdrift shoreline, the reduction in solid discharge produced a severe erosion effect in the section where divergence is seen in the net drift direction.

\section{CONGLUSIONS}

Although it is recognized that there are a number of limitations in the present model, which include different levels of uncertainty, the results give a convenient approximation that allows a first-order correlation between the coastal dynamics in the São Francisco River mouth and the severe erosion phenomenon that is currently occurring there. The results also suggest that the permanent reduction in solids discharged by the São Francisco River, resulting from the construction of the large dams, will probably have two direct consequences on the estuary region: (i) chronic erosion of the shoreline on the downdrift side of the shoreline and (ii) possible evolution of the delta system to the category "deflected delta influenced by wave" proposed by BHATTACHARYA and GiosAN (2003), with the progressive deflection of the mouth in the downdrift direction.

\section{ACKNOWLEDGMENTS}

A.C.S.P. Bittencourt, J.M.L. Dominguez, and D.L. Sousa thank CNPq (National Council for Scientific and Technological Development), the first two for their Research Fellowship Grant, and the third for the Scientific Initiation Scholarship. I.R. Silva thanks CAPES (Coordenaçäo de Aperfeiçoamento de Pessoal de Nível Superior) and CNPq, respectively, for Masters and Ph.D. scholarships. We acknowledge an anonymous reviewer for their comments and suggestions.

\section{LITERATURE CITED}

BAccocoli, G., 1971. Os deltas holocênicos brasileiros-Uma tentativa de classificação. Boletim Técnico da Petrobrás, 14 (1/2), 538 .

Barbosa, L.M., 1997. Campos de dunas costeiras associadas à desembocadura do Rio São Francisco (SE/AL): origem e controles ambientais. Bahia, Brazil: Universidade Federal da Bahia, Instituto de Geociências, Ph.D. thesis, 203p.

Barbosa, L.M. and Dominguez, J.M.L., 2003. Coastal dune fields at the São Francisco River strandplain, northeastern Brazil: morphology and environmental controls. Earth Surface Processes and Landforms, 29, 443-456.

BASCOM, W.J., 1954. The control of stream outlets by wave refraction. Journal of Geology, 62, 600-605.

BHATTACHARYA, J.P. and GiosAN, L., 2003. Wave-influenced deltas: geomorphological implications for facies reconstruction. Sedimentology, 50, 187-210.

Bittencourt, A.C.S.P.; Dominguez, J.M.L.; Martin, L., and FerREIRA, Y.A., 1982. Dados preliminares sobre a evolução do delta do Rio Francisco (SE/AL) durante o Quaternário: influência das variações do nível do mar. In: Suguio, K.; MeIs, M.R.M., and TESSLER, M.G. (eds.), IV Simpósio do Quaternário Costeiro do Brasil (Rio de Janeiro, Brazil), pp. 49-68.

Bittencourt, A.C.S.P.; Dominguez, J.M.L.; Martin, L., and SiLVA, I.R., 2000. Patterns of sediment dispersion coastwise the State 
of Bahia, Brazil. Anais da Academia Brasileira de Ciências, 72, 271-287.

Bittencourt, A.C.S.P.; Martin, L.; Dominguez, J.M.L.; Silva, I.R., and SousA, D.L., 2002. A significant longshore transport divergence zone at the northeastern Brazilian coast: Implications on coastal Quaternary evolution. Anais da Academia Brasileira de Ciências, 74, 505-518.

Bittencourt, A.C.S.P.; Dominguez, J.M.L.; Martin, L., and SilVA, I.R., 2005. Longshore transport on the northeastern Brazilian coast and implications to the location of large-scale accumulative and erosive zones: An overview. Marine Geology, 219, 219-234.

CERC (Coastal Engineering Research Center), 1984. Shore Protection Manual. Washington, D.C.: U.S. Army Corps of Engineers, V. I, 597p.

Coleman, J.M. and WRIGHT, L.D., 1972. Delta morphology in relation to the discharge/wave power climate. In: Anais XXVI Congresso Brasileiro de Geologia (Belém, Brazil), pp. 145-155.

DaviES, J.L., 1972. Geographical variation in coastal development. New York, U.S.A.: Longman, 204p.

DHN (Diretoria de Hidrografia e Navegação), 1983. Brasil-Costa Leste: Barra do Rio São Francisco do Norte. Rio de Janeiro, Brazil Ministério da Marinha, Carta Náutica no 1002, escala: 1:20,000.

Dominguez, J.M.L.; BitTencourT, A.C.S.P., and MARTin, L., 1983. O papel da deriva litorânea de sedimentos arenosos na construção das planícies costeiras associadas às desembocaduras dos rios São Francisco (SE/AL), Jequitinhonha (BA), Doce (ES) e Paraíba do Sul (RJ). Revista Brasileira de Geociências, 13, 98-105.

Dominguez, J.M.L.; Martin, L., and BitTenCOURT, A.C.S.P., 1987. Sea-level history and the Quaternary evolution of river mouthassociated beach-ridge plains along the east-southeast coast of Brazil: a summary. In: Nummedal, D., Pilkey, D.H., and HowARD, J.D. (eds.), Sea-Level Fluctuation and Coastal Evolution. Tucson, Arizona: Society of Economic Paleontologists and Mineralogists Special Publication 41, pp. 115-127.

Dominguez, J.M.L., 1996. The São Francisco strandplain: a paradigm for wave-dominated deltas? In: DE BAPTIST, M. and JACOBS, P. (eds.), Geology of Siliciclastic Shelf Seas. London: Geological Society of London Special Publication 117, pp. 217-231.

Dominguez, J.M.L., 1999. Erosão Costeira na Região Leste-Nordeste do Brasil. Bahia, Brazil: Universidade Federal da Bahia, Instituto de Geociências, Full Professor thesis, 175p.

Dominguez, J.M.L.; BitTencourt, A.C.S.P.; Martin, L.; Oliveira, M.B.; Silva, R.; Andrade, A.C.S.; Lavenere-Wanderley, A.A.O.; Freitas, L.M.B.; Queiroz, I.G. and SiLVA, I.R., 2003. Tendências de Erosão Costeira nos Estados da Bahia e Sergipe. In: Anais IX Congresso da ABEQUA (Recife, Brazil), CD-ROM (not sequentially numbered).

Fontes, A.L., 2001. Processos erosivos na desembocadura do Rio São Francisco. In: Boletim de Resumos, VIII Congresso da $A B E$ QUA (Imbé, RS, Brazil), pp. 66-67.

FonTES, L.C.S. and HolandA, F.S.R., 2002. Estudo do processo erosivo das margens do baixo São Francisco e seus efeitos na dinâmica de sedimentação do rio. Aracaju, SE, Brazil: Relatório Final Projeto GEF São Francisco (ANA/GEF/PNUMA/OEA), Subprojeto $2.4,512 \mathrm{p}$.

FranÇA, A.M.C., 1979. Geomorfologia da margem continental leste brasileira e da bacia oceânica adjacente. In: CHAves, H. (ed.), Geomorfologia da margem continental brasileira e das áreas oceânicas adjacentes. Rio de Janeiro, Brazil: Série Projeto REMAC № 7, Petrobrás/Cenpes, pp. 89-127.

Galloway, W.E., 1975. Process framework for describing the morphologic and stratigraphic evolution of deltaic depositional systems. In: Broussard, M.L. (ed.), Deltas, Models for Exploration. Houston, Texas: Houston Geological Society, pp. 87-98.

Hogben, N. and Lumb, F.E., 1967. Ocean wave statistics. London, England: National Physical Laboratory, Ministry of Technology, $263 p$.

KAMPHIUS, J.W., 1991. Alongshore sediment transport rate. Journal of Waterways, Port, Coastal and Ocean Engineering, 117, 624-641.

Кокот, R.R., 1997. Littoral drift, evolution and management in Punta Médanos, Argentina. Journal of Coastal Research, 13, 192-197.

Komar, P.D., 1976. Beach process and sedimentation. New Jersey, U.S.A.: Prentice Hall, $429 p$.

KomaR, P.D., 2000. Coastal Erosion-underlying factors and human impacts. Shore and Beach, 88, 3-16.

MunK, W.H. and TraYlor, M.A., 1947. Refraction of ocean waves; a process linking underwater topography to beach erosion. Journal of Geology, 55, 1-26.

Nimer, E., 1989. Climatologia do Brasil. Rio de Janeiro, Brazil: Instituto Brasileiro de Geografia e Estatística, 421p.

Oliveira, A.M.; Segundo, G.H.C.; SANTos, R.C., JR.; Hernandez, A.O., and MATos, A.E., 2002. Caracterização Hidrodinâmica-sedimentológica do Baixo São Francisco. Aracaju, Sergipe, Brazil: Relatório Final Projeto GEF São Francisco (ANA/GEF/PNUMA/ OEA), Subprojeto 1.1.A, 325p.

Oliveira, A.M.; Santos, R.C., JR.; Hernandez, A.O.; Segundo, G.H.C., and ARAúJo, A.E.M., 2003. A morte do delta do Rio São Francisco. In: Anais IX Congresso da ABEQUA (Recife, Brazil), CD-ROM.

Oliveira, M.B., 2003. Caracterização integrada da linha de costa do Estado de Sergipe, Brasil. Bahia, Brazil: Universidade Federal da Bahia, Instituto de Geociências, Master's thesis, 102p.

Silva, F.R.; Dominguez, J.M.L., and BitTencourt, A.C.S.P., 2001. Variações morfodinâmicas da barra de desembocadura do Rio São Francisco e sua influência no clima de ondas. In: Boletim de Resumos, VIII Congresso da ABEQUA (Imbé, RS, Brazil), pp. 503504.

Stanley, D.J. and Warner, A.G., 1998. Nile Delta in its destruction phase. Journal of Coastal Research, 14, 794-825.

Vital, H.; Oliveira, A.M., and TABosa, W.F., 2001. Caracterização de Padrões de Formas de Fundo da Foz do Rio São Francisco. Pesquisas em Geociências, 28, 125-131.

White, K. and El Asmar, H.M., 1999. Monitoring changing position of coastlines using thematic mapper imagery, an example from the Nile Delta. Geomorphology, 29, 93-105.

WRIGHT, L.D. and Coleman, J.M., 1973. Variations in morphology of major river deltas as functions of ocean waves and river discharge regimes. American Association of Petroleum Geologists Bulletin, 57, 370-398.

YounG, I.R. and Holland, G.J., 1996. Atlas of the Oceans: Wind and Wave Climate. Oxford, England: Pergamon, 238p.

Zenkovitch, V.P., 1967. Processes of Coastal Development. London, England: Oliver \& Boyd, 738p. 